\title{
Les problématiques et les principaux défis des femmes entrepreneures : une étude qualitative
}

\author{
Yves Robichaud, Ph. D., CGA - Université Laurentienne \\ Egbert McGraw, Ph. D., FCGA - Université de Moncton \\ Jean-Marie Nkongolo-Kakenda, Ph. D. - Université de Régina \\ Yvon Gasse - Université Laval
}

\section{INTRODUCTION}

De plus en plus de femmes se lancent en affaires. À titre d'exemple, en 2001 près de la moitié des PME canadiennes comptaient au moins une entrepreneure comme propriétaire pour un total d'environ 715500 PME. En 2000, les PME où les femmes étaient propriétaires majoritaires, soit $18 \%$ des PME, ont géneré des recettes annuelles de 72 milliards de dollars soit $8 \%$ environ de l'ensemble des recettes des PME canadiennes. Étant donné l'augmentation rapide du nombre de femmes entrepreneures d'une part, et leur contribution à l'économie canadienne d'autre part, il est nécessaire de poursuivre les recherches sur ce sujet, d'autant plus que le profil des femmes entrepreneures évolue, et que les caractéristiques de leur entreprise, l'environnement ainsi que leurs problématiques changent également. C'est dans cette perspective que la présente recherche est proposée. Concrètement, cette étude tente de trouver réponse à la question de recherche suivante : Quels sont les problématiques et les défis auxquels sont confrontées les femmes entrepreneures en général? Pour répondre à cette question, l'étude a eu recours à des entretiens de groupe et individuels auprès d'entrepreneures. L'utilisation de groupes de discussion et d'entretiens individuels comme méthodologie de recherche permettra d'obtenir une compréhension plus profonde de notre sujet d'étude.

\section{PROBLÉMATIQUES ET DÉFIS DES FEMMES ENTREPRENEURES}

Les écrits sur les femmes entrepreneures rapportent qu'il existe des problématiques propres à ces dernières notamment l'accès au financement, la fréquentation à des réseaux et le conflit travail-famille ${ }^{1}$. Entre autres, ces études rapportent que la gestion des conflits entre les responsabilités personnelles et celles liées au travail était un problème souvent mentionné par les femmes entrepreneures. Comme la plupart des entrepreneurs masculins, les femmes en affaires sont mariées et ont des enfants. Cependant, contrairement aux hommes, ce sont souvent elles qui doivent assumer les responsabilités liées au travail de la maison. Parmi les facteurs qui seraient à l'origine de ces conflits, on dénote un manque de support de la famille, un revenu instable et incertain, le risque de pertes financières, des longues heures de travail ainsi qu'un niveau élevé de stress. L'équilibre entre les responsabilités familiales et les exigences de l'entreprise est une source de pres- sions additionnelles pour les femmes en affaires. Cette source de pressions se traduit par le manque de temps et d'énergie pour faire ce qu'il y a à faire (p. ex. réfléchir aux problèmes financiers et fixer des priorités), par un manque de vie sociale et de participation à des réseaux et par des pressions de leur famille pour être plus disponible.

L'équilibre entre les responsabilités familiales et les exigences de l'entreprise est une source de pressions additionnelles pour les femmes en affaires.

Une autre préoccupation spécifique aux femmes qui démarrent ou qui opèrent une entreprise est celle du financement et de l'accès au crédit ${ }^{2}$. Deux grandes tendances semblent se dégager de l'étude de ce problème : un premier groupe de chercheurs soutient qu'il existe une discrimination dans l'attribution des prêts selon le genre 
de l'emprunteur. Selon ces auteurs, les femmes obtiendraient des prêts avec des conditions moins favorables que ceux des hommes notamment des taux d'intérêts plus élevés ainsi que des garanties plus importantes seraient exigées sur les prêts consentis aux femmes. Un second groupe de chercheurs tentent de démontrer que les difficultés d'accès au financement seraient plutôt liées à des caractéristiques propres à l'entreprise (taille, âge, secteur d'activité) plutôt qu'à une discrimination envers les femmes.

Les femmes obtiendraient des prêts avec des conditions moins favorables que ceux des hommes notamment des taux d'intérêts plus élevés ainsi que des garanties plus importantes seraient exigées sur les prêts consentis aux femmes.
Finalement, la participation à des réseaux d'affaires est un facteur déterminant dans le succès d'une entreprise. Tous les chercheurs s'accordent pour dire que c'est un élément clé de la performance entrepreneuriale ${ }^{3}$. Ainsi, plus une entrepreneure a un réseau en affaires élaboré ou développé et plus elle en profitera, meilleures seront ses chances de succès. Cependant, la notion de réseau est souvent absente ou peu présente dans les activités journalières des femmes entrepreneures. Celles-ci n'ont souvent pas le temps, en raison des contraintes familiales, de participer activement à des associations de gens d'affaires. Les femmes entrepreneures ont donc tendance à sous-utiliser les réseaux. Pour les fins de cette recherche, le cadre d'analyse est illustré à la figure 1 .

Figure 1 : Entrepreneuriat féminin : les contraintes et problématiques

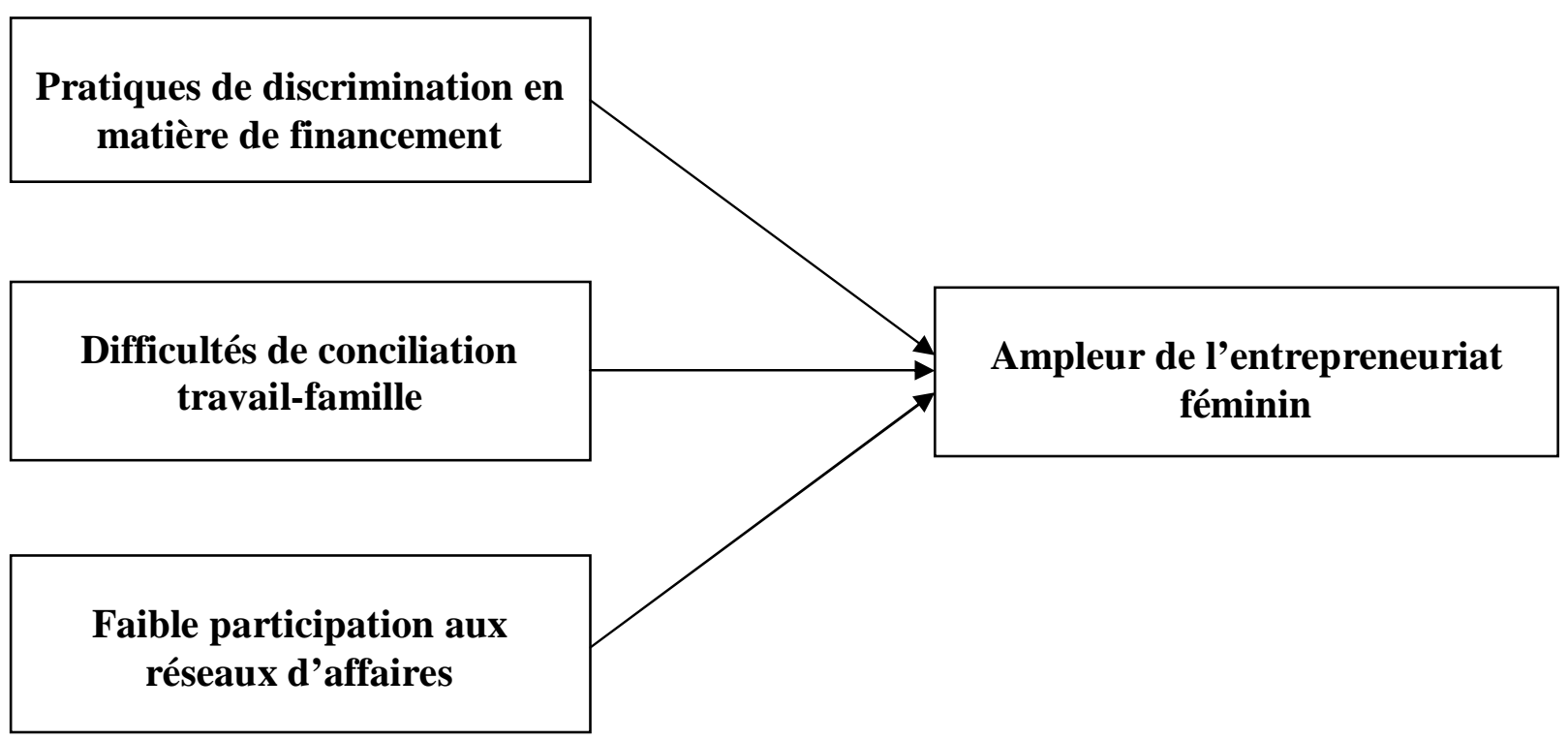

\section{MÉTHODOLOGIE}

La présente étude a eu recours à des groupes de discussion et des entretiens individuels ayant comme sujet des entrepreneures du NouveauBrunswick, de l'Ontario et de la Saskatchewan ${ }^{4}$. Les entreprises constituant l'échantillon ont été sélectionnées de façon non probabiliste. En tout 32 entrepreneures ont participé aux sessions de groupe ou aux entretiens individuels. Au
Nouveau-Brunswick, 2 rencontres ont eu lieu soit une à Grand-Sault (5 participantes) et l'autre à Fredericton ( 2 participantes) pour un total de 7 participantes. En Saskatchewan, 2 groupes de discussion ont eu lieu à Régina pour un total de 9 participantes. Enfin, en Ontario, des entretiens individuels ont permis la participation de 16 entrepreneures. Les groupes de discussion et 
les entretiens individuels ont porté sur les thèmes suivants : 1) les obstacles/problèmes rencontrés durant le démarrage ou la conduite de leur entreprise en général y compris ceux liés à la recherche de financement, à la conciliation

\section{RÉSULTATS}

\subsection{Profil des répondants}

Le tableau 1 résume les renseignements recueillis auprès des répondantes. Les résultats obtenus révèlent que toutes les entreprises œuvrent dans les secteurs de service ou de détail, qu'elles ont favorisé dans une proportion de $88 \%$ la création de leur entreprise par rapport à travail-famille et à la participation à des réseaux d'affaires; 2) les principaux défis auxquels les femmes entrepreneures devront faire face dans le futur. Les résultats de ces entretiens sont présentés dans la section qui suit.

l'acquisition et qu'elles sont, en majorité, âgées entre 30 et 50 ans $(72 \%)$. Quant aux caractéristiques organisationnelles, les résultats démontrent que 23 des 32 entreprises comptent moins de six employés et que 18 , soit $56 \%$ d'entre elles, ont un chiffre d'affaires de moins de $100000 \$$.

Tableau 1 - Profil des répondantes et de leurs entreprises $(n=32)$

\begin{tabular}{|c|c|c|}
\hline Variables & Total & urcentage \\
\hline $\begin{array}{ll}\text { Secteur d'activités } \\
-\quad \text { détail } \\
-\quad \text { service }\end{array}$ & $\begin{array}{r}9 \\
23\end{array}$ & $\begin{array}{l}28 \% \\
72 \%\end{array}$ \\
\hline $\begin{array}{l}\text { Débuts dans l'entreprise } \\
-\quad \text { Création } \\
-\quad \text { Acquisition }\end{array}$ & $\begin{array}{r}28 \\
4\end{array}$ & $\begin{array}{l}88 \% \\
12 \%\end{array}$ \\
\hline $\begin{array}{l}\text { Nombre de partenaires/actionnaires } \\
-\quad 1 \\
-\quad 2 \\
-\quad 4\end{array}$ & $\begin{array}{r}22 \\
9 \\
1\end{array}$ & $\begin{array}{r}69 \% \\
28 \% \\
3 \% \\
\end{array}$ \\
\hline $\begin{array}{l}\text { Nombre d'employés (y compris les } \\
\text { propriétaires) } \\
\text { - } 1 \text { employé (propriétaire) } \\
\text { - } \quad 2 \text { à } 5 \text { employés } \\
\text { - } \quad 6 \text { à } 10 \text { employés } \\
\text { - } \quad 11 \text { employés et + }\end{array}$ & $\begin{array}{r}10 \\
13 \\
4 \\
5\end{array}$ & $\begin{array}{l}31 \% \\
41 \% \\
12 \% \\
16 \%\end{array}$ \\
\hline $\begin{array}{l}\text { Chiffre d'affaires } \\
-\quad 0-100000 \$ \\
-\quad 100001 \$-500000 \$ \\
-\quad 500001 \$-1000000 \$ \\
-\quad \text { Pas répondu }\end{array}$ & $\begin{array}{r}18 \\
9 \\
3 \\
2\end{array}$ & $\begin{array}{r}56 \% \\
28 \% \\
10 \% \\
6 \%\end{array}$ \\
\hline $\begin{array}{l}\text { Âge de l'entrepreneur } \\
-\quad 20 \text { à } 30 \text { ans } \\
-\quad 30 \text { à } 40 \text { ans } \\
-\quad 41 \text { à } 50 \text { ans } \\
-\quad 51 \text { ans et plus } \\
\end{array}$ & $\begin{array}{r}2 \\
10 \\
13 \\
7\end{array}$ & $\begin{array}{r}6 \% \\
31 \% \\
41 \% \\
22 \%\end{array}$ \\
\hline $\begin{array}{l}\text { Langue maternelle } \\
-\quad \text { autre } \\
-\quad \text { français } \\
-\quad \text { anglais }\end{array}$ & $\begin{array}{r}2 \\
14 \\
16\end{array}$ & $\begin{array}{l}6 \% \\
44 \% \\
50 \%\end{array}$ \\
\hline
\end{tabular}




\subsection{Difficultés importantes rencontrées dans la recherche de financement}

\section{Plusieurs femmes entrepreneures ont} investi de leurs poches tandis que d'autres ont eu recours à la signature de leur mari ou étaient solides financièrement avant de partir en affaires.

Selon les commentaires recueillis sur ce thème, la majorité des répondantes n'ont pas eu à emprunter beaucoup pour lancer leur entreprise, ni pour l'opérer. Plusieurs femmes entrepreneures ont investi de leurs poches tandis que d'autres ont eu recours à la signature de leur mari ou étaient solides financièrement avant de partir en affaires. La synthèse des données et informations porte à croire que les femmesentrepreneures sont soumises à des conditions sévères et des contraintes supplémentaires en matière d'accès au crédit et aux sources de financement. Sur ce point, les commentaires de plusieurs répondantes confirment cette tendance de discrimination dans l'attribution des prêts.

«I dealt with the Caisse Populaire and if I was to go elsewhere to try and get a loan, chances are really good that I wouldn't get one. But because the Caisse Populaire knows me, because I've been a client for years, they know that if they give a loan I'll make the payments. »

«On a pris une décision au début qu'on ne s'endetterait pas beaucoup... C'est pour cette raison qu' on n'a pas beaucoup de dettes avec les banques et nous réinvestissons (nos profits) dans notre commerce... On n'a pas eu beaucoup de difficultés parce qu' on n'a pas cherché pour obtenir du financement. » «Both my partner and I when we started out we had very secure banking backgrounds and yet we did run into some stumbling blocks at some banks. And we didn't borrow a lot of money. »

«Celles qui ont emprunté ont connu toutes sortes de difficultés. Plusieurs ont perçu que les bailleurs de fonds demandaient plus d'information parce qu' elles étaient des femmes. Elles ont attribué leurs difficultés à obtenir du financement au fait qu'elles étaient des femmes. Les récits de certaines illustrent bien ce point de vue.» «Quand tu commences seulement (une entreprise) ils ont peur, il faut vraiment prouver qu'on est capable de le faire avant qu'ils t'aident pour l'aide financière $» . . . \ll$ Being a woman, we couldn't access funding at all to start the business. Because, at the time, there had been a lot of changes, they weren't giving a lot of money for small business so we had to rely on all of our personal money. » «On a présenté notre plan d'affaires à une institution financière que je ne nommerai pas, puis c'est comme si on ne nous a pas pris au sérieux. Ils ne nous écoutaient pas à cause que nous étions des femmes. Nous sommes ensuite allées voir l'institution financière où nous faisons affaires et là nous avons bien été traitées. » «Comme j'ai dit avant, quand tu commences, ils veulent vraiment que tu aies du succès avant de te donner de l'argent, puis c'est vrai qu'ils veulent te faire sentir que tu n'es pas sérieuse parce que tu es une femme. »

\subsection{Conciliation entre le travail et la famille}

\section{Les femmes-entrepreneures ont deux emplois : opérer l'entreprise, mais aussi opérer la maison-famille avec toutes les responsabilités inhérentes à cette dimension.}

Tel que suggéré dans le cadre de cette recherche, les données et informations recueillies auprès des répondantes indiquent que la conciliation entre le travail et la famille exige d'énormes sacrifices. Les femmesentrepreneures ont deux emplois : opérer l'entreprise, mais aussi opérer la maison-famille avec toutes les responsabilités inhérentes à cette dimension.

La conciliation travail-famille a donné lieu à des commentaires intéressants qui peuvent se résumer en trois observations. D'abord, plusieurs répondantes s'entendaient pour dire que le support de leur mari était un facteur important dans la conduite de leur entreprise. Sur ce point, divers commentaires sont éloquents.

«One thing I cannot forget, is that my husband as been amazing with my kids. He did buy in to 
the whole business proposition but he doesn't always like it. But he's really good with our family so I cannot take that away from him. If he hadn't been so much help with our children, I probably wouldn't be able to do this right now. (With his help) I am able to balance. » «My husband takes care of all the home so I am able to, at this point in my life, dedicate this much time to the business. Younger families would have a lot more trouble trying to balance the two. »

« Well for me I think I'm exceptionally lucky in the way that the business that I run is for children so I get to bring my kids here, my step kids and the little guy that I'm adopting. They get to hang out here whenever I need them to and its actually fun for them. As far as my husband is concerned, he's really supportive and he's very independent. So we can live happily together with as much time together or as little time as the week requires and our family life just balances fine that way. » «J'ai tendance à dire que ça a beaucoup changé parce que les hommes nous supportent beaucoup plus maintenant qu'avant. »

«I look at things a little differently (than most women). My family bought into this when I started. My husband knew that this was going to be a little of a nightmare. My kids knew, my kids are older so it makes it easier compared to having small kids. But I still have two children at home. But it's also a family business, so even my husband who has a very stressful career sometimes finds himself licking envelopes. But I think having the family own it and doing it for you're family helps. Even having your own business, they don't have to be involved but they have to buy into it. And I think that's the biggest challenge for a woman. You can't just be mom, you have to be the entrepreneur and the mom and the wife and something for yourself. Finding that balance is really tough. I think I found it but that's only because I demanded it. And I think we've survived. I think it's easier for a man. When a man goes into business, the rest of the family buys in. When a woman goes into business, you have to convince them. It's very stressful that way. »
Ensuite, d'autres entrepreneures ont reconnu qu'elles étaient très occupées mais habituées à porter plusieurs chapeaux et qu'elles devaient s'organiser en conséquence comme le démontrent les commentaires suivants : "Sometimes very well and other times not so well. I try to get my work done while my son is at school and then sometimes I'll work really early in the morning and other times I'll work really late at night. But that also gives me the opportunity to participate in school activities... But in general, you spend your time in different ways and you have to make up for your time. Instead of working nine to five like regular people, you might work like 6 to 7:30 and 8:30 till $3 \mathrm{pm}$. And if you have more you do it after they're in bed... » «Ben, moi j'ai deux adolescentes, je cours, je cours, je cours beaucoup, on priorise...c'est vraiment des priorités. » «On est accoutumé de tout faire, on fait le taxi, on fait à manger, on fait le ménage, et on travaille dans notre entreprise. »

\section{Les femmes-entrepreneures impliquent les enfants dans l'entreprise, mais insistent sur la nécessité d'avoir une vie normale, c'est- à-dire que les affaires ne doivent pas envahir la vie familiale.}

Enfin, selon les données obtenues, les femmesentrepreneures impliquent les enfants dans l'entreprise, mais insistent sur la nécessité d'avoir une vie normale, c'est-à-dire que les affaires ne doivent pas envahir la vie familiale, comme l'illustrent les commentaires suivants: «Pour moi et mon mari, ça a toujours été qu'on était pour impliquer nos enfants. Nos enfants sont des jeunes adultes maintenant. Les deux, ma fille et mon garçon, ont travaillé dans le magasin... Mais, il faut avoir un équilibre et être capable, lorsqu'on est à la maison, de laisser les petits problèmes de côté pour avoir une vie un peu normale. » « J'essaie d'inclure mes enfants et ma famille dans mon entreprise. On essaie de trouver autant de temps que possible pour passer avec eux autres...» «Moi j'avoue que j'ai un foyer de soin et mon mari et mes filles sont là aussi. Ca fait que j'ai beaucoup plus de temps avec eux autres. » 


\subsection{Participation à des réseaux d'affaires}

\section{En tant que facteur capital dans le succès d'une entreprise, la participation à des réseaux d'affaires s'avère très faible chez les femmes entrepreneures, compte tenu des responsabilités diverses qu'elles assument.}

En tant que facteur capital dans le succès d'une entreprise, la participation à des réseaux d'affaires s'avère très faible chez les femmes entrepreneures, compte tenu des responsabilités diverses qu'elles assument. En général, très peu de femmes ont dit participer à des réseaux d'affaires faute de temps. Lorsqu'elles participent, c'est la Chambre de Commerce de la région qui est l'organisation la plus souvent citée. Plusieurs témoignages vont dans le sens de cette proposition : « No I don't. Because of a lack of time... » «I don't belong to any business networks... I don't have time for that. » «I belong to the Chamber of Commerce and I don't necessarily think that that's a great thing. I don't think it has a lot to offer. But because the reputation is there that if you're a member of the chamber you're somehow more reputable. So I'm a member to take advantage of that concept. » « Je commence juste alors je n'ai pas trop le pied dans des réseaux mais j'ai l'intention d'en joindre un.» «Non pas encore. Mais c'est quelque chose que je vais regarder. »

\subsection{Se doter de ressources humaines compétentes : une quête permanente}

\section{Les femmes entrepreneures font aussi face à une pression permanente : l'embauche d'employés compétents et loyaux semble constituer la principale préoccupation des entrepreneures interrogées. En effet, la majorité des entrepreneures ont avoué que cela constituait un sérieux problème pour leur entreprise.}

Les femmes entrepreneures font aussi face à une pression permanente: l'embauche d'employés compétents et loyaux semble constituer la prin- cipale préoccupation des entrepreneures interrogées. En effet, la majorité des entrepreneures ont avoué que cela constituait un sérieux problème pour leur entreprise, comme l'illustrent les perceptions des femmes-entrepreneures interviewées à travers les témoignages suivants :

«C'est de trouver des employés qui vont être loyaux. Il y a beaucoup de compétition au niveau des petites entreprises. On sait que ce sont les petites et moyennes entreprises qui vont toujours développer l'économie. La compétition entre les entreprises fait que c'est difficile de trouver des employés qui sont loyaux et de les garder heureux. Je pense que cela est le plus grand «challenge» d'une petite et moyenne entreprise. » « Hiring employees. In my field of business there really isn't enough education in this field. There's no schooling that will teach you this. So for training, there's a lot of money put out in training and we tried to get funding for that through the government and we can't. It's not into a trade so you can't really get an (apprentice)... » « Too many clients, not enough time and not enough of me. Finding help is also difficult because you want to find people who do quality work. You want to find people that take pride in their work and people who have integrity and people who are honest. Finding a person who has all those qualities is very difficult and to grow it's necessary to farm out»

«Barriers, aside from the financial aspect, I think, generally, my biggest challenge has been...our partnership was challenging and I have had a great deal of challenge of staffing, the unemployment rate in our areas is $3 \%$, but the challenge has nothing to do with other than the fact that it's a restaurant. »

La compétition entre les entreprises fait que c'est difficile de trouver des employés qui sont loyaux et de les garder heureux. Je pense que cela est le plus grand « challenge » d'une petite et moyenne entreprise. 


\section{PRINCIPAUX DÉFIS DES FEMMES ENTREPRENEURES DANS LE FUTUR}

La majorité des commentaires recueillis sur ce thème peuvent être regroupés autour de plusieurs catégories : la discrimination dont font l'objet les femmes en affaires et les progrès réalisés sur ce point, l'équilibre travail-famille, l'importance de valoriser le métier d'entrepreneure et la nécessité de disposer de ressources humaines compétentes. À cet égard, la figure illustre cette tendance constatée.

\section{Figure 2 - Défis de l'entrepreneuriat féminin}

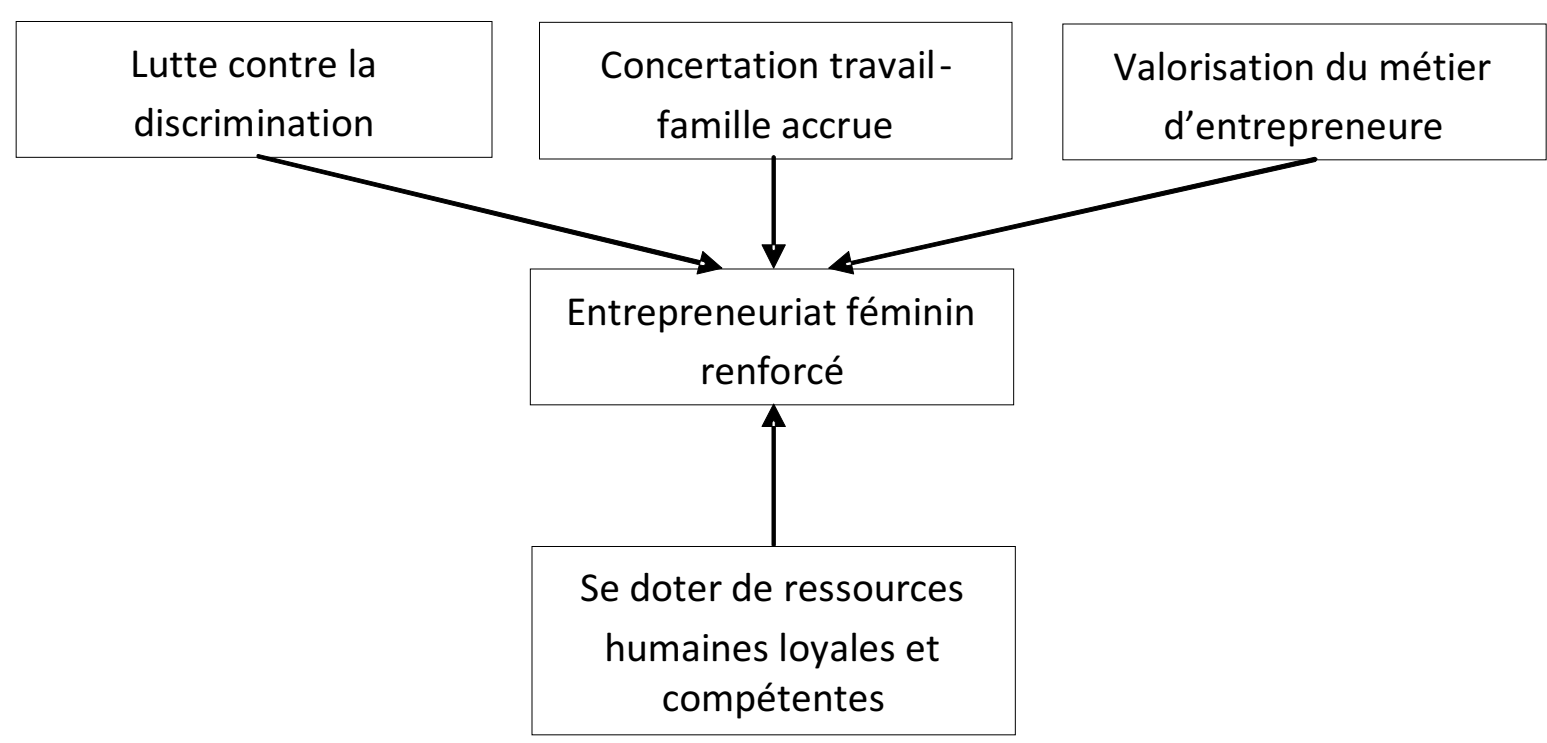

Dans le but de mieux saisir la portée des défis de l'entrepreneuriat féminin, les commentaires de certaines femmes entrepreneures méritent d'être mentionnés. «Balancing your family, taking care of yourself and taking care of your business. I think society expects women to continue to be the care giver that they've been in the past. It's difficult to be everything to everyone, especially as a business owner. Women basically have to check their guilt at the door and go on and do what they need to do and do the best they can do. »

"One of the biggest challenges is that, regardless of what society says is equality, it's still been proven that women do a lot more at home than the husband does. So there's to kind's right. There's just mothers in general, who are still expected to carry probably 60$80 \%$ of the family household responsibilities while still trying to run her business. On the other side, a man can work on his business and will be forgiven for his family responsibilities. As for single mothers, which I am one, I find it's double that because there's nobody there to pick up the slack. So either the lawn doesn't get raked or something doesn't get done just because there are other priorities... »

«I think the main challenge...is...I would not have been able to have succeeded this year if I had a family or if I had other commitment, because I've had both grants past, because just even the involvement that always comes back traditionally to the women to take care of the family, to take care of the business and to take care of this and that and everything else...you have so many other jobs that you do and a friend of mine would love to be here, but unfortunately, she is an independent business women, she has a family so there are so many commitments and so you find yourself looking after two generations beside your own and you also look after your company and our business 
so I think that balance is going to be a challenge with any women in business. »

«I think for females, and this is only from my perspective because I really don't know a whole lot of other men who are in business who feel the same way. But I think for females, we're kind of worry warts by nature and we over analyze by nature so it's kind of tricky to worry about the business and about the husbands and the kids and all of that. I think that time, being able to organize your time and prioritize properly; that's the big thing for female entrepreneurs. »

«I think that women entrepreneurs in the future will face less than what we did. I think kids are being raised differently than they were 40 years ago. My son is being raised much differently than how my husband was raised. I have older daughters that are married and their relationships are much different. They both work and have always worked. So I think female entrepreneurs will have it easier as I don't see the same discrimination I seen 20 years ago. People in unemployment didn't encourage women to become entrepreneurs as they do now. I think we have an opportunity now to grab that ring and go. I think we're

\section{CONCLUSION}

\section{Sur le plan conciliation travail-famille, une forte proportion des femmes interrogées ont avoué que le support de leur mari était un facteur important dans le fonctionnement de leur entreprise.}

Cette étude qualitative visait à acquérir une meilleure compréhension du phénomène de l'entrepreneuriat féminin. Plus spécifiquement, l'objectif de l'étude visait à en apprendre davantage sur les problématiques et les défis auxquels font face les entrepreneures en général.

En résumé, les renseignements recueillis de cette étude qualitative relativement aux problèmes rencontrés par les entrepreneures font ressortir que celles-ci n'ont pas eu à emprunter beaucoup pour lancer leur entreprise ou qu'elles étaient solides financièrement avant de partir en paving the path for them. Society has changed in the past 40 years. »

« There are still some barriers between, when you're trying to get other services even though I am a woman and I've been in business for a few years, there are still some men that are still (old fashioned). They still don't really feel that women should be in business. Some of those barriers are still there and even in the funding through the banks and everything else, they still rely on a man's signature for a lot of it. » «Being my age, I'm in a different frame of view. I think there are still people who feel that women should not be active in the business activity. In the future, I think that women have to be very aware of being assertive but not aggressive. » «Il faut que les femmes apprennent à mieux valoriser le métier d'entrepreneur. Il y a beaucoup de femmes qui sont entrepreneures comme des coiffeuses et des esthéticiennes qui ne se considèrent pas entrepreneures. Pourtant, elles sont entrepreneures au même titre que la plupart des hommes et cela même si elles n'ont pas beaucoup d'employés. » «J e pense qu'un des défis est d'apprendre aux femmes à valoriser davantage leur rôle d'entrepreneures parce que ce n'est pas un titre connu par tout le monde. »

affaires. Celles qui ont eu des difficultés à obtenir du financement attribuent cela au fait qu'elles sont des femmes. Sur le plan conciliation travail-famille, une forte proportion des femmes interrogées ont avoué que le support de leur mari était un facteur important dans le fonctionnement de leur entreprise. De plus, les femmes entrepreneures devaient s'organiser de façon à concilier les responsabilités familiales et les responsabilités d'affaires ce qui n'était pas une tâche facile et que les enfants étaient souvent impliqués dans l'entreprise. Par ailleurs, les entrepreneures participent peu ou pas aux réseaux d'affaires faute de temps. Enfin, l'embauche d'employés compétents et loyaux constitue leur principale préoccupation.

Quant aux défis, les entrepreneures s'entendent pour dire que la discrimination envers les 
femmes en affaires, l'équilibre travail-famille et l'importance de valoriser le rôle d'entrepreneure représentent les principaux défis des femmes entrepreneures dans le futur.

Notre étude comporte certaines limites. En effet, compte tenu de la nature restreinte de l'échantillon, du type de recherche (qualitative), de la restriction sectorielle (service et détail) et géographique (N.-B., Saskatchewan et Ontario), elle ne permet pas de dégager des conclusions pouvant être généralisées à l'ensemble des petites entreprises canadiennes, ni des petites entreprises en général.

\section{BIBLIOGRAPHIE}

${ }^{1}$ Scarborough, N.M. et T.W. Zimmerer. (2000). Effective Small Business Management, 6th Edition, New Jersey, Prentice-Hall, Inc.; Coleman, S. (2002). «Constraints faced by women small business owners: evidence from the data », Journal of Developmental Entrepreneurship, vol. 7, no 2, p. 151-173.; Bruni, A., S. Gherardi et B. Poggio. (2004). «Entrepreneurmentality, gender and the study of women entrepreneurs », Journal of Organizational Change Management, vol. 17, no 3, p. 256-268.; Greve, A. et Salaff, J. (2003). «Social Networks and Entrepreneurship », Entrepreneurship Theory and Practice, Fall, p. 1-22.; Sheldon, L.M. (2006). « Female Entrepreneures, Work-Family Conflict, and Venture Performance: New Insights into the Work-Family Interface », Journal of Small Business Management, vol. 44, no 2, p. 285-297.; Orser, B., A. Riding et K. Manley. (2006). «Women Entrepreneures and Financial Capital», Entrepreneurship Theory and Practice, vol. 30, no 5, p. 643-665.; Carter, S, E. Shaw, F. Wilson et W. Lam. (2007). «Gender, Entrepreneurship and Bank Lending: The Criteria and Processes Used by Bank Loan Officers in Assessing Applications », Entrepreneurship Theory and Practice, vol. 31, no 3, p. 427-444.

${ }^{2}$ Coleman, S. (2000). « Access to capital and terms of credit: a comparison of men and women-owned small businesses », Journal of Small Business Management, vol. 38, no 3, p. 37-52.; Riding, A. L. et C.S. Swift. (1990). "Women business owners and terms of credit: some empirical findings of the Canadian experience », Journal of Business Venturing, vol. 5, no 5, p. 327-340; Coleman, S. (2002). « Constraints faced by women small business owners: evidence from the data», Journal of Developmental Entrepreneurship, vol. 7, no 2, p. 151-173.
Gouvernement du Canada (2002). Small and Medium-sized Enterprise (SME) Financing in Canada dans Survey on Financing of Small and Medium Enterprises. Ottawa, Ontario: Statistics Canada.

${ }^{3}$ Shaw, E, W. Lam, S. Carter et F. Wilson. (2006). «Theory, Practice and Policy: An Integrated View on Gender, Networks and Social Capital », Congrès du International Council for Small Business.; Filion, L.J. (1990). «Entrepreneurial performance, networking, vision and relations», Journal of Small Business Entrepreneurship, vol. 17, no 3. P. 3-13.; McGregor J. et D. Tweed. (2000). Women managers and business owners in New Zealand, dans Davidson, M., J. et R.J. Burke, Women in management: current research issues, Thousand Oaks, Ca: Sage, p. 40-52.; St-Cyr, L. et Gagnon, S. (2004). «Les Entrepreneures Québécoises: Taille des Entreprises et Performance», Congrès International Francophone en Entreprenneurship et PME, Montpellier, France.

${ }^{4}$ Les participantes aux groupes de discussion du N-B ont été sélectionnées avec l'aide du «Acadia Centre for social and business entrepreneurship » à partir de listes d'entrepreneures inscrites à leurs séminaires de formation professionnelle tandis que celles de l'Ontario ont été sélectionnées à partir de listes d'entrepreneures fournies par le Centre Régional des affaires de la ville de Sudbury et du Regroupement des femmes d'affaires et des femmes professionnelles du même endroit. Quant aux entrepreneures de la Saskatchewan, nous avons eu recours à la liste de l'Association des femmes entrepreneures de la Saskatchewan. 


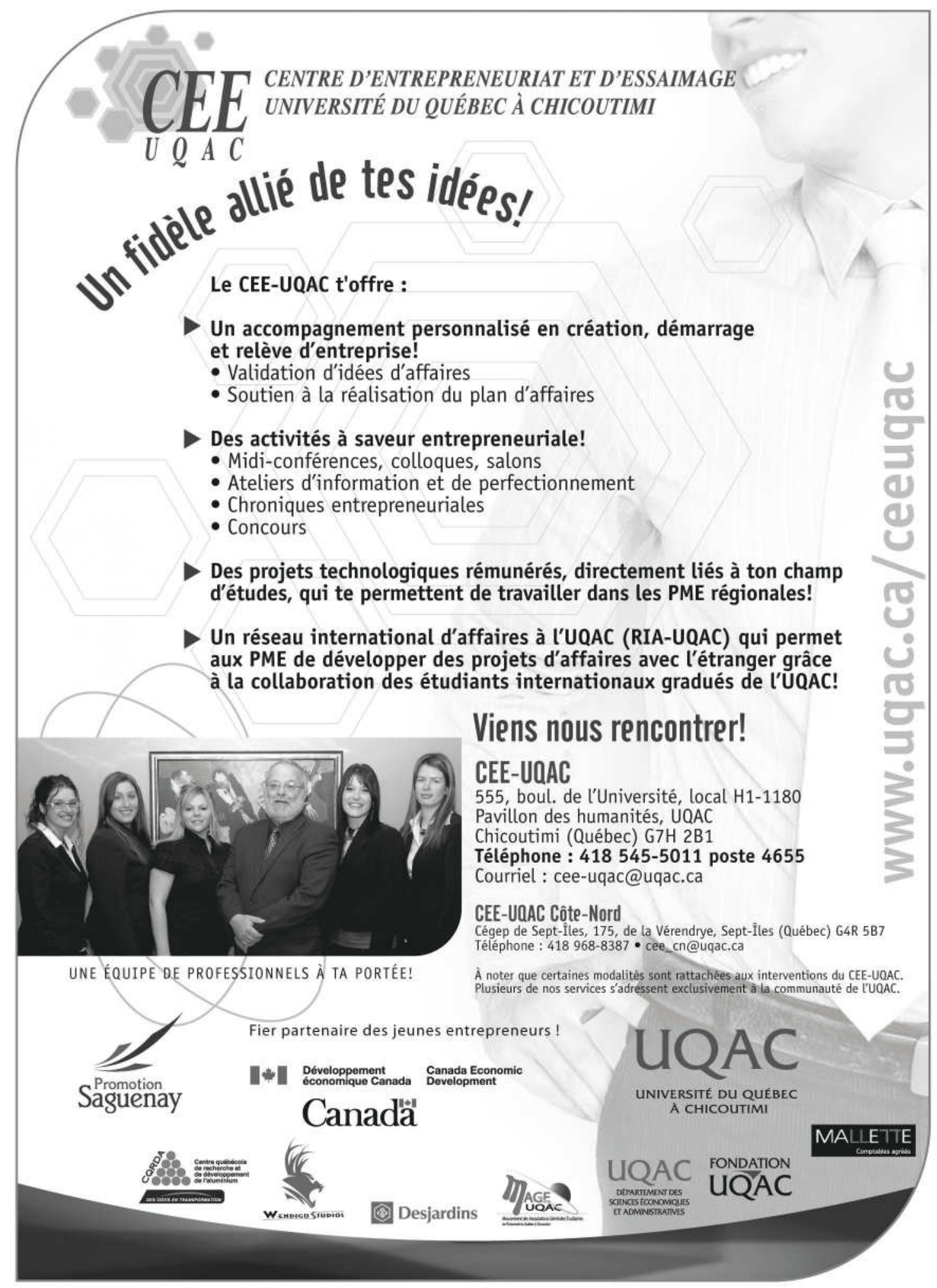

